\title{
Makotek as a Tourist Attraction in Munggu Village, Bali
}

\author{
Gede Yoga Kharisma Pradana ${ }^{1}$, I Wayan Pantiyasa ${ }^{2}$ \\ ${ }^{1}$ Hotel Management, International Bali Tourism Institute \\ ${ }^{2}$ Hotel Management, International Bali Tourism Institute \\ Email: 1'yoga@stpbi.ac.id, and ²pantiyasa@stpbi.ac.id.
}

\begin{abstract}
The purpose of this study is to comprehend the Makotek as a tourist attraction in village Munggu, Bali. In general, the tourism destination will be developed in sustainable way if it has many touristic potentials. Meanwhile, the phenomena in Munggu village is different. Although this village doesn't have hospitality resources or special tourism event, but every Kuningan, Munggu is always full of tourists to witness the Makotek. The questions are : (1) How is the Makotek performed?; (2) Why are the tourists interested to watch?; (3) How is the management could be developed in sustainable way?

This study utilized qualitative method. Type and source data are obtained through observation, interview, FGD and literary study. The entire data is analyzed by using interdiciplinary approach.

The result shows that : (1) The Munggu people march in a parade carrying the ceremonial equipments going around of Munggu village. At every cross section, they make the pyramids; (2) The tourists are interested to watch Makotek because, it contains esthetic ideology and self-actualisation ideology; (3) Makotek until now can be developed because it gives creative economy contribution. It could strengthen the foundation of social relation in managing local cultural tradition in global era.
\end{abstract}

Keywords-Makotek; Munggu Village; Tourist Attraction

\section{INTRODUCTION}

The purpose of this research is to understand the Makotek tradition as a tourist attraction of Munggu Village, Bali. This research is conducted because it has imbalance between the concept of tourist destinations with tourism phenomenon in the village of Munggu, Bali. Medik in Ariyanto (2005) said that a tourism activity can occur due to the offer of tourist destinations. Medlik asserted that, there is at least an attraction, accessibility, amenities and ancillary that support tourism activities and attract from tourist to visit in a tourist destination. A good destination for tourists should have natural resources, infrastructure, accommodation, hotel resources, target markets, commodity care systems, government involvement in development and maintenance of tourist destinations, tourism commodities and competitors (Robert C. Lewis and Richard E Chambers, 1989). To further motivate tourists to visits a tourist destination, a synergistic system of combined tourism products and services, communities, tourism institutions and tourism actors in creating entities in a geographical region can provide the totality of experience for tourists (Aby Legawa, 2008). Therefore, it can be understood that a tourist destination ideally has a tourist commodity, there are tourism activities, tourism institutions, public facilities and hospitality resources and the environment is managed and can motivate tourist visits through promotional activities of tourism actors.

In contrast to the tourism phenomenon that occurred in the village of Munggu. Although the village does not have a tourist commodity, accessibility and public facilities adequate for tourism activities. There is no tourism institution and adequate hospitality and environmental resources for tourism activities, but every six months precisely on the day Kuningan, Munggu Village is always crowded with tourists to watch the Makotek. In fact, Munggu village has not been developed and promoted as a tourist village. Althought, Makotek is only found in the village of Munggu and it is not deliberately presented as a tourism commodity for tourists. The question are : (1) What is the Makotek tradition? (2) Why are tourists interested on it ?; (3) How is it managed? 


\section{LITERATURE REVIEW}

Tourist attractions can be defined as anything that can attract tourists to a tourist destination. Marioti in Yoety (1996: 172) categorizes tourist attractions as: a) natural objects including natural amenities such as clean water, sunny day, land configurations and landscape, the sylvan element, uncommon vegetation, wild life, national park, hunting and photographic , b) health center like natural spirling mineral water, mud baths and hot springs. c) man made supply like historic, cultural and religious objects. d) the way of life, the traditional living arrangement of a society includes customs and habits of life.

Makotek isn't tourism event. Makotek is a cultural attraction in Munggu village that always appeals to tourists. Makotek events always involve historic objects of local cultural and religious value, so Makotek can be understood as a form of representation of Munggu customs and habits of life. Specifically, Makotek is an oral tradition as a ritual of unfortunately for Indigenous people of Munggu Village, Badung. The tradition is held for purification their community based every six months, precisely every Kuningan day. As a Unfortunately ceremony, Makotek is very distinctive. At that time, all male came out carrying pullet wood stick. They roamed around the Munggu village area accompanied by balaganjur with religious songs. Until now, Munggu villagers believes that by implementing Makotek, they will obtain safety, comfort zone and avoid the outbreak of epidemics in Munggu village.

Munggu isn't tourist village. Munggu is an rural area close to the Government Center of Badung Regency and Tanah Lot tourism object in Bali. Administratively, Munggu Village is one part of Mengwi District, Badung Regency, Bali Province. Munggu village is the entrance to the district of North Kuta and South Kuta. The area is $1.5 \mathrm{~km}$ to the north or south of the subdistrict Mengwi, Badung, Bali.

Geographically, the Munggu Village area is adjacent to the following regional villages. The north: Cepaka Village. The east: Tumbak Bayuh Village. The south: the Indonesian Ocean. The west: Penet River. Munggu area has a village with distance from the district government center about $15 \mathrm{~km}, 8 \mathrm{~km}$ from the district capital, $25 \mathrm{~km}$ from the provincial capital and 1,300 km from the nation's capital.

\section{METHODS}

This research is done by using qualitative method. Types and sources of data both primary and secondary research was obtained through observation techniques, interviews, FGD and literature study. All the data collected is analyzed by using qualitative with interdicplinary approach.

\section{RESULT AND DISCUSSION}

\section{A. What is Makotek tradition?}

As a tradition of tolak bala ceremony for driving away evil spirits, Makotek has a relatively large form because it is held in bulk by involving participants up to one village. Makotek mentions can not be separated from the suggestion to integrated kotekan up to sound tek..tek .. tek to prevent the occurrence of disaster. In order to tackle disaster preventively, the participants walked in crowd to bring the ceremonial equipment to Puseh temple. Puseh Temple is a marker of the beginning and the end of Makotek in Munggu village.

Makotek held in the afternoon at around 13:00 pm. The commencement of Makotek's implementation is marked by the sound of kulkul on every banjar. After all the participants had gathered, sacred objects that had been prepared to be paraded in the Makotek series were collected. The young men called truna gede brought all the ceremonial equipments to Puseh Munggu Temple followed by the koteker, each carrying pulley wood stick decorated with pandan, tamiang and plawa. Sacred objects include tamiang kolem, tri-sakti spear and keris previously stored in a number of temples Munggu also issued to be prepared in Makotek. Hendropuspito (1983: 99-102) and Palmer (2005: 152-153) say that sacred objects must go through the process of sacralization. As the heritage 
objects that will be used in the Makotek tradition have been sacralized by the stakeholders to prevent outbreaks of disasters.

Makotek Is held by people marching with their own respective roles. The first row carrying the kotekan starts the journey followed by groups of holly objects, such as holy spear and tamiang kolem, temple priests carrying sacred weapon, the gong musical group, the sekaa santhi and followed by the Hindu followers wandering around the village.

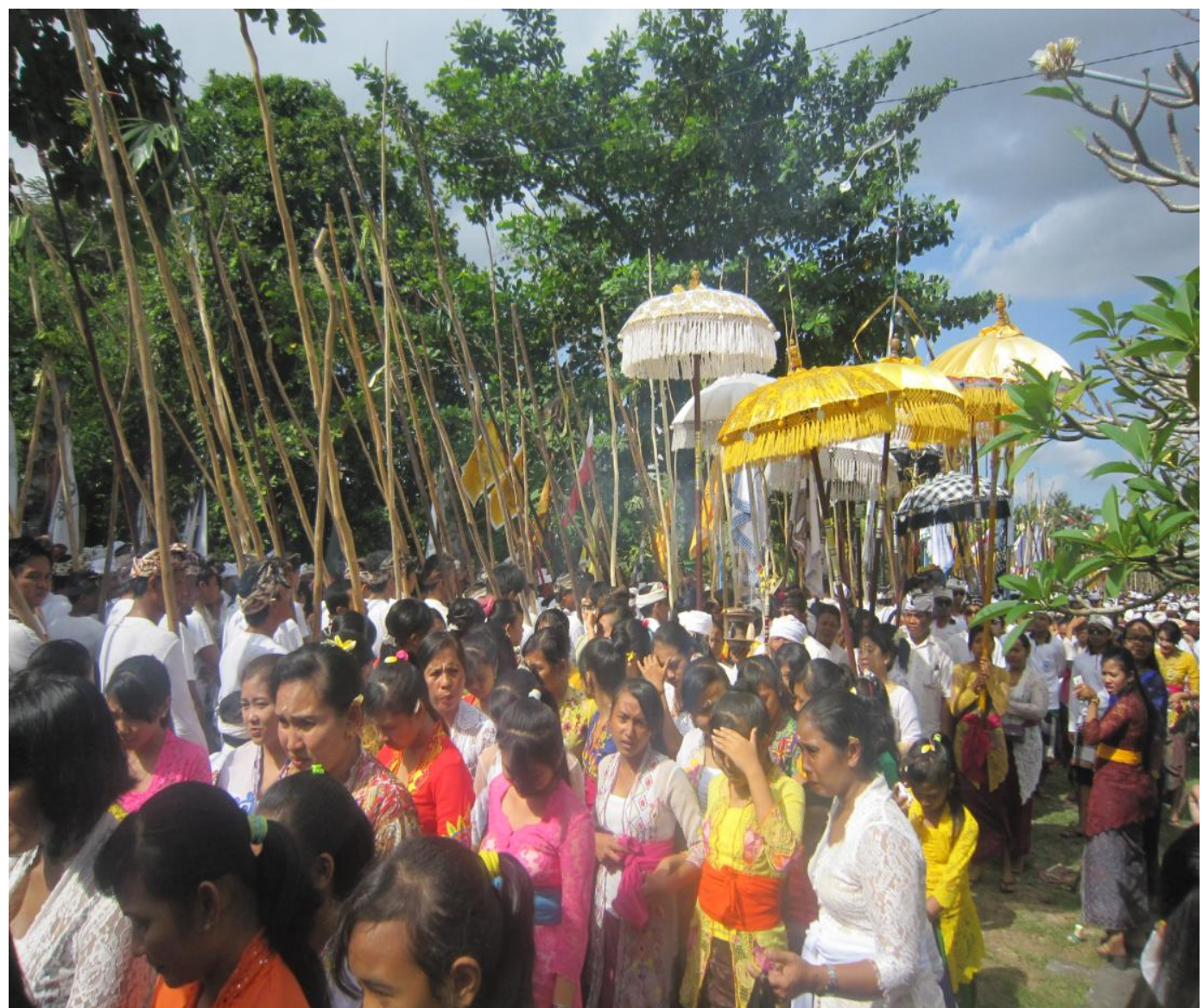

Fig. 1 Makotek Ceremony

(Source: Yoga, 2014)

\section{B. Why are tourists interested on Makotek?}

Tourists are interested in watching Makotek because it gives a different vibration and freshness that reinforces the festive mood of the event. Where from the atmosphere of festivity that always anticipated strongly influenced by aesthetic ideology and self-actualization ideology.

First, aesthetic ideology is rooted in the desire and need for beauty. It has motivated the actors to assemble each component of the activity. Makotek is presented in a special way in all of its operation. The movement is implemented in a sustainable manner and has full institutional support in order to strengthen the form of appreciation and offerings in the context of the ceremony. In the context of the ceremony, aesthetics have been seen from the selection of locations and activities. The activities are designed through several temples full of ornate sculptures with the beauty of a combination colors and reinforced by the characteristics of truth and leadership ethics by characterizations of legends and mythology as the basis of aesthetically and prominently aesthetic philosophy.

Specifically, the Makotek's activity aesthetic has began from the stage of offering preparation, religious songs, gamelan performance, in which the outfit is purposefully selected and decorated to celebrate the holiday. During the Makotek ceremony, the koteker's show of force takes place. 


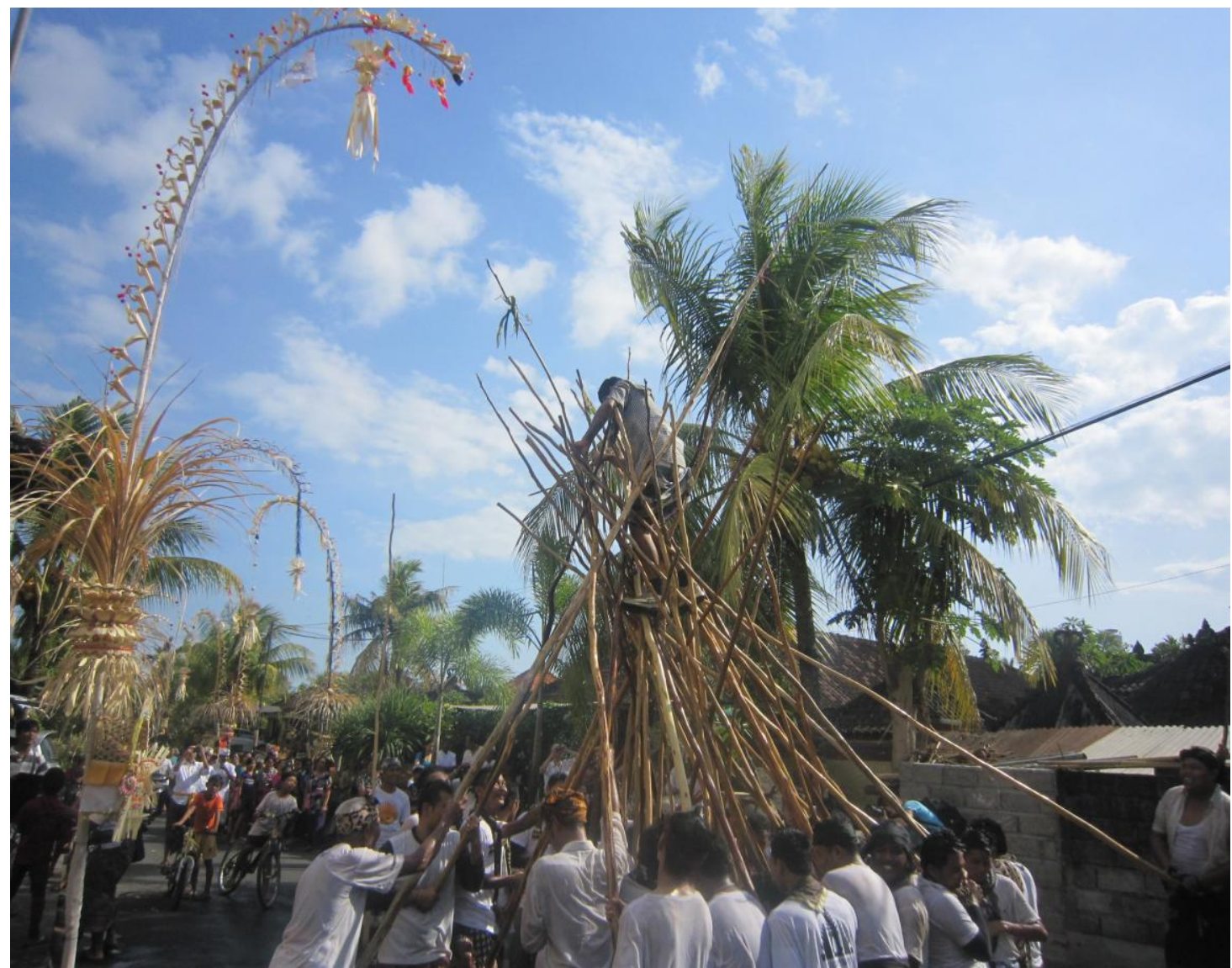

Fig. 2 Makotek Attraction

(Source: Yoga, 2014)

Based on the above photo, it can be observed that, there are two koteker dancing on a clump of wood like pyramids on Makotek. In this regard, the art form has been transformed into a cultural representative hoped by Makotek participants. The excitement of Makotek procession is supported by gamelan.

Each selected gamelan group tries to accompany the attraction Makotek with the best. Rising gamelan sound makes the ceremony atmosphere more vibrant. Art adaptively can bring its participants closer in the religious atmosphere (Mantra, 1996: 26-27; Suamba, 2006: 3). Where in this case, artistic expression seeks to strengthen the nature of religiosity in ceremonial symbols that already have implications for mutual satisfaction.

Second, this actualization ideology stems from the performers existential desire according to the current situation and condition. The process of actualization often times involves an adaptive change for achieving its existence. Identity recognition is in this case very important as the participant of Makotek, therefore the way they run the activity will differ in each year's celebration, especially in terms of uniform.

As a mass Balinese activity, the uniform actually show traditional outfit to display the collective cohesive in ceremonial practice. Beside, it is not only the participants who are changed with the younger ones, the costumes also set in colourful but uniform way to display happiness of being involved in Makotek.

Self-actualization is mostly done when they built the kotekan wood formation. The pyramid formation is generally constructed by numerous koteker, although few kotekers may also built the same shape. Not only a mere pyramid construction, sometimes a brave participant climbs into the construction. We can sometimes witness the construction being bumped onto each other and marched around.

It is interesting to note that when a participant successfully climbs the pyramid from a pile of kotekan always dances or shows creative action. The action can be acrobatic, as the actors perform different movements that seem strange, unique until other actors have been able to do more attractions 
above the clump of kotekan. The incident caused an astonishment, amazement that invite the laughter of the tourists for the action.

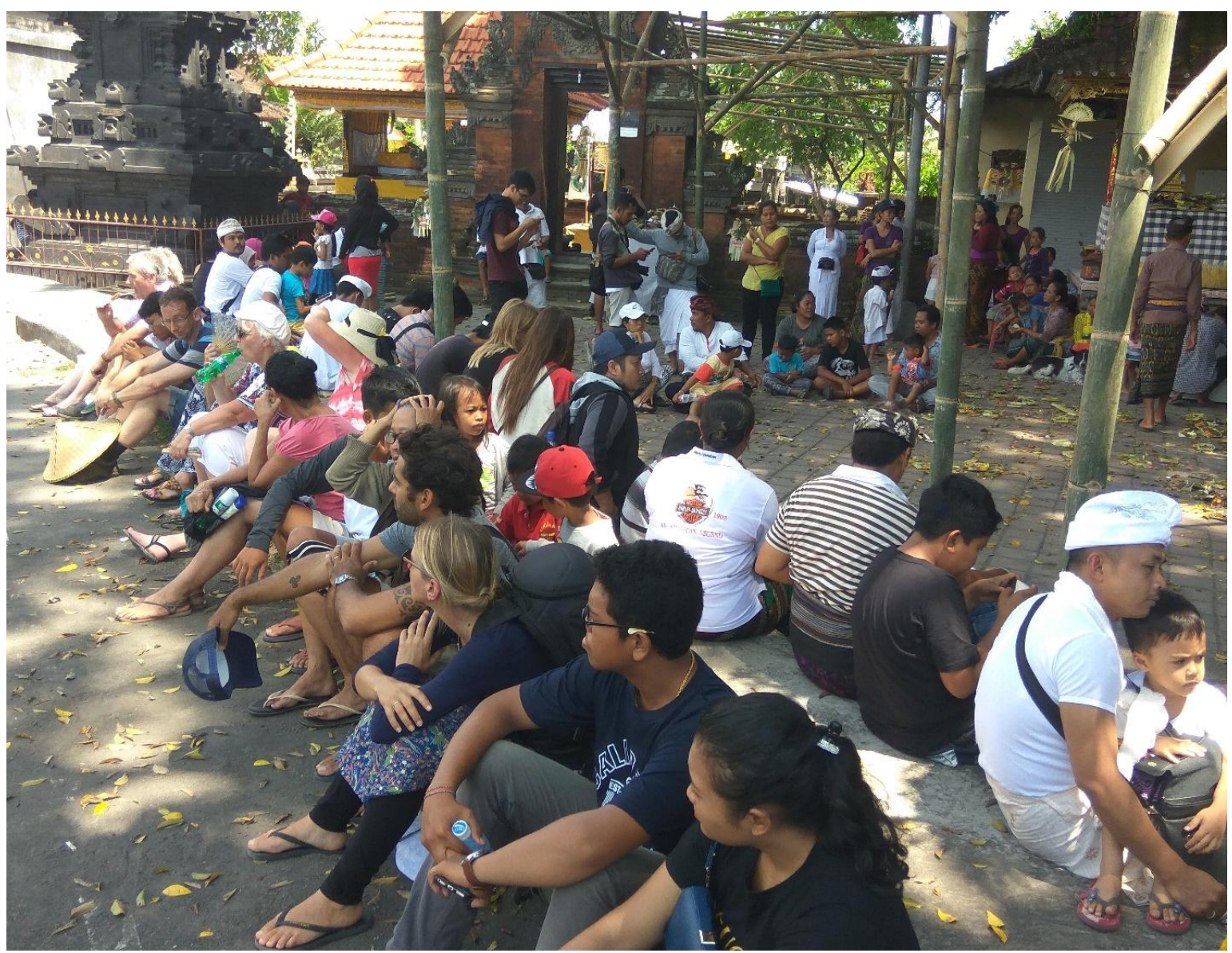

Fig.3 Tourist's of the Makotek audience

(Source: Yoga, 2017)

Based on the photo above the atmosphere of the tension from the tourists when watching the Makotek attraction. The most anticipated atmosphere when at least two actors on top of the pyramid of kotekan collide and fall inviting cheers from the other participants as a form of excitement and gratitude, but still in an atmosphere of togetherness. The subject also attracted more attention from tourists, even among them often imitate the style of the koteker to cure the curiosity as well as trying to dive and feel the atmosphere of emotion from the perpetrators for free. 


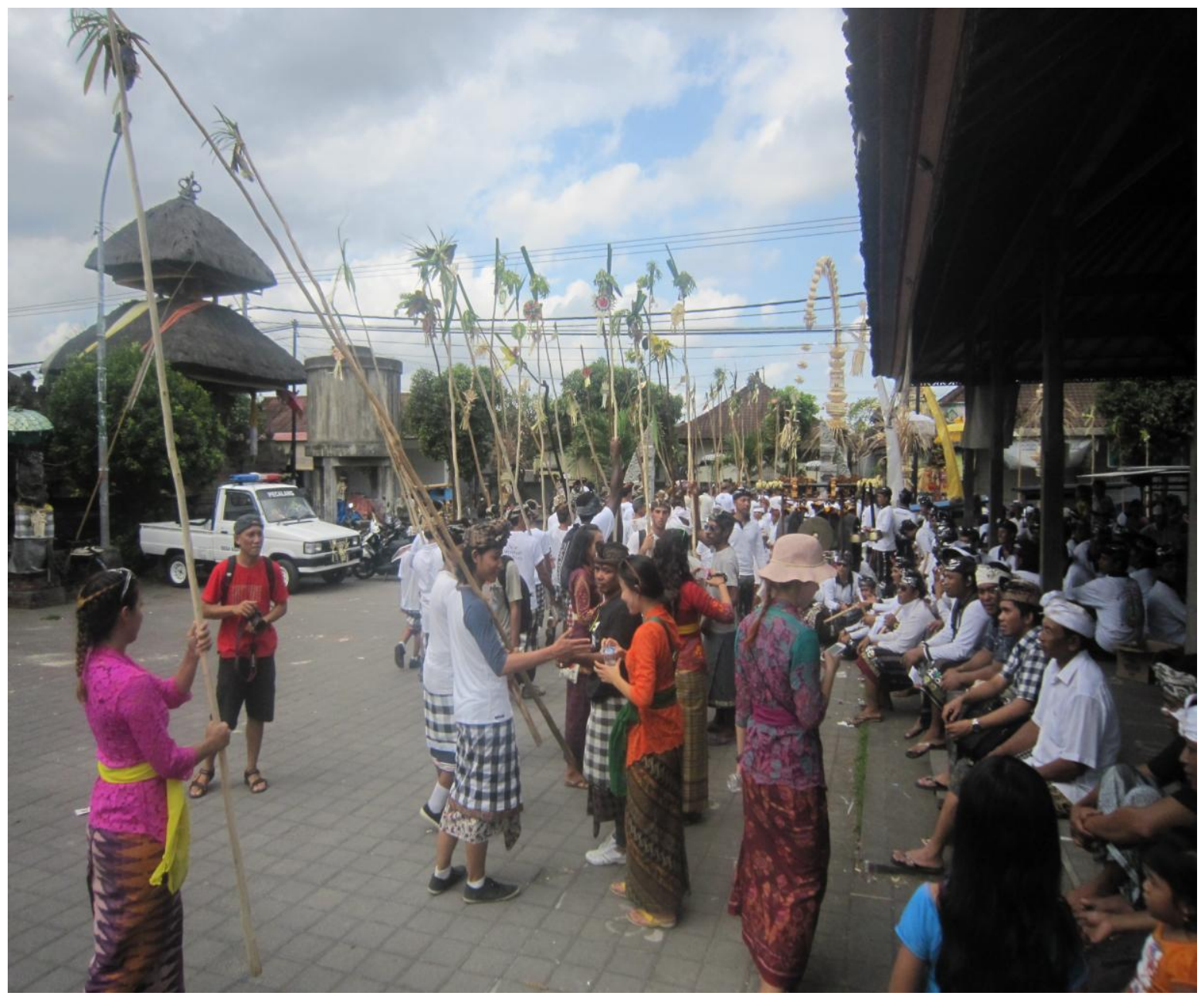

Fig. 4 Tourist Reaction

(Source: Yoga, 2015)

Based on the photo above a tourist trying to imitate the style of the koteker. Such action to participate to strengthen the festivity, giving different vibration that are anticipated tourists and add to the freshness of the atmosphere of the ceremony.

\section{How is Makotek Makotek managed?}

Tradition up to now can be developed sustainable community as the tourist attraction of Munggu Village because the implementation is done oriented creative economy. Various activities take place and emerge in local culture since the institution preparation of Makotek post-meeting finished. In makotek preparation, the participants are led by bendesa adat. The bendesa adat holds a meeting to elect the prime representative to organize Makotek from banjars. The atmosphere of the Makotek preparatory meeting like this. 


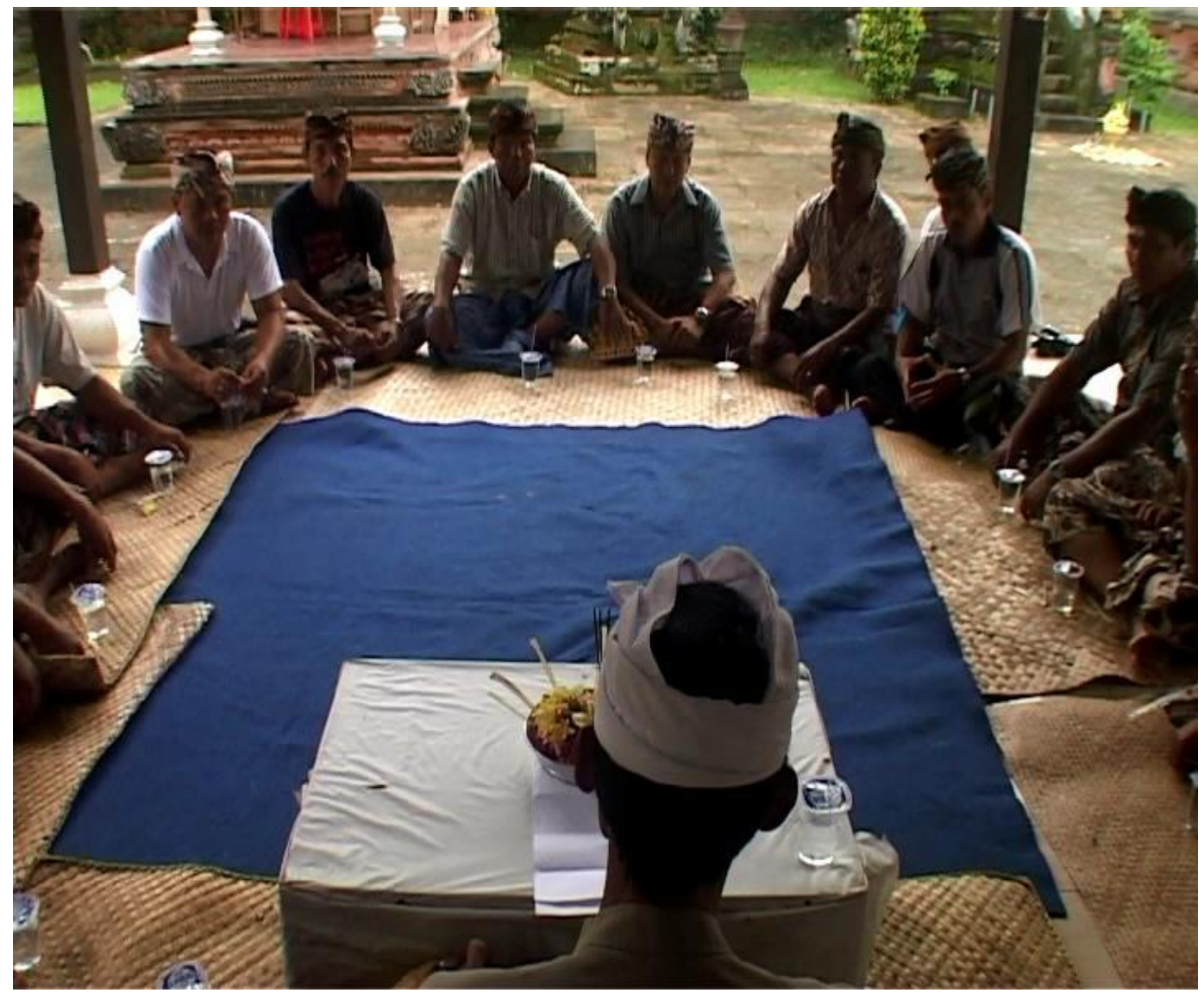

Fig. 5 Makotek Meeting

(Source: Yoga, 2015)

The election is then followed up by deciding the theme and the creative work of each participants, including monitoring the activity preparation to consolidations through coordination religious leader and government, in terms of the amount of contribution of expenses and energy, independently by the participant consecutively to optimize the Makotek. In the implementation, a series of activities conducted by participants based on bendesa adat instruction, endorsed by the temple priest's and secured by the pecalang. More specifically, the readiness of each participant is managed intensely on enculturation.

The regeneration of Makotek in principle uses the media of cultural values that are carried out verbally. The inheritance of cultural values from Makotek tradition is presented in the family environment as the first social group to introduce cultural values to the child. Basically, Makotek inheritance is verbally more effectively done in the institution of each family. 


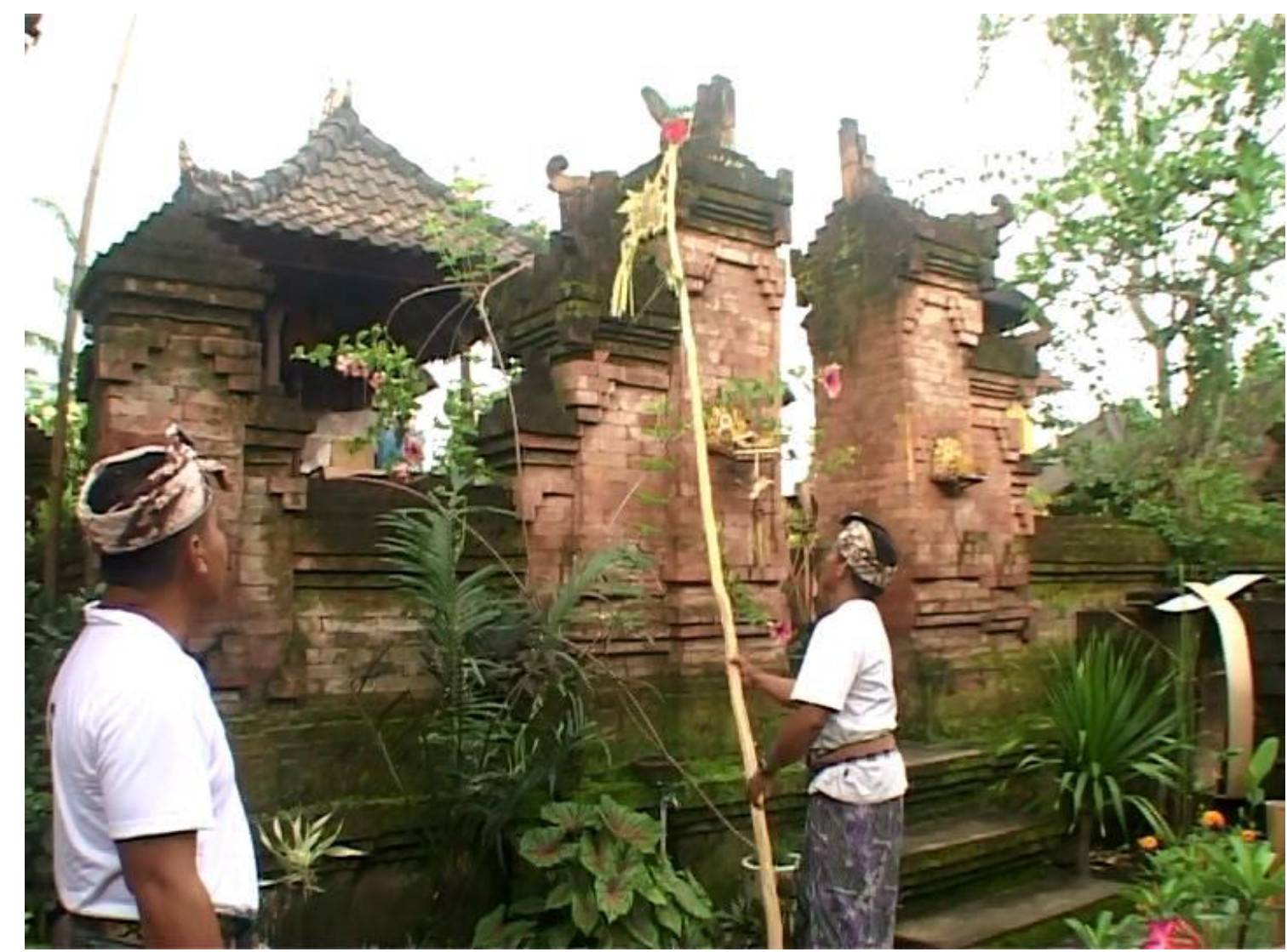

Fig. 6 Makotek Reinvention

(Source: Yoga, 2015)

From the photo above, it can be observed a pattern of enculturation makotek culture within the scope of the family. The family becomes the institution for the habitus which, according to Bourdieu in Randal (2010), is capable of producing a variety of practices to improve fortune. Makotek can be implemented until now, inseparable from the encouragement and rule of the seniors, related to the process of cultural heritage in a family. Inheritance is done through reinvention. Sedyawati (2012: 414) suggests that the pattern of reinvention is done by direct appointment action in a performance to a few technical modifications. The pattern is done by giving a direct example to the heirs using tools intensely related to the strengthening of cultural values and cultural heritage in community relations in the village of Munggu.

\section{CONCLUSION}

Based on the results of the discussion, it can be concluded as follows :

1) Makotek is a tolak bala ceremony tradition reinforcements performed local communities every six months, precisely every Kuningan day. All villagers of Munggu villagers walk in crowd carrying ceremonial equipment such as spears, banners, wood pullet around Munggu village accompanied by singing religious songs and gamelan. At each intersection they spin round and pitted against the strength of the pulleys carries until it ranges from the ground to the building resembling the pyramids. 2) Tourists interested in watching the Makotek because it have aesthetic ideology and selfactualization ideology. Aesthetic ideology encourages creativity in ceremonial activities to be more beautiful than usual, while self-actualization ideology encourages creativity in continuous rejuvenation including participants, costumes, upakara to formations that provide another atmosphere in terms of cultural attractions. With other meanings, tourists are interested to come to the village of Munggu because it has cultural attractions that are beautiful, continuously rejuvenated and can be enjoyed for free. 
3) Institutionally, Makotek until now can be developed sustainable community as the tourist attraction of Munggu Village because the implementation is done oriented creative economy. The mutual benefit of mutual cooperation is increasingly felt after donations are managed more modern by involving government, religious leaders and custom leaders to strengthen the strong base of local social relations in the management of local cultural traditions in the global era.

Based on the research results can be suggested as follows. The researchers are advised to explore and find things that have not been revealed in the phenomenon of tourist attractions in the framework of community empowerment.

\section{REFERENCES}

Ariyanto., Ekonomi Pariwisata., Rineka Cipta.,2005.

Hendropuspito., Sosiologi Agama., Gunung Mulia., 1983.

Legawa, Aby. Komponen Produk Pariwisata Dengan Acuan Khusus. Gramedia Pustaka, 2008.

Lewis, Robert C., and Richard E. Chambers., Marketing Leadership in Hospitality: Foundations and Practices., Van Nostrand Reinhold, 1989.

Mantra, Ida Bagus., Landasan Kebudayaan Bali., Yayasan Methuen., 1985.

Palmer, Richard., Hermeneutika : Teori Baru Mengenai Intepretasi (terj.)., Pustaka Pelajar, 2005.

Randal, J. Alder, Alvin Arens and Mark S. Beasley. Auditing and Assurance Services: An Integrated Approach (edisi 13)., Pearson Education, Inc, 2010.

Sedyawati, Edi., Budaya Indonesia: Kajian Arkeologi, Seni dan Sejarah., Rajawali Press, 2012.

Suamba, Ketut., Bahan Ajar Manajemen Produksi dan Operasi Agribisnis. Program Magister Agribisnis Unud, 2006.

Yoety, Oka., Pengantar Ilmu Pariwisata., Angkasa., 1996. 